\title{
Beberapa Kendala dalam Penyelesaian Status Hukum Tanah Bekas Swapraja di Daerah Istimewa Yogyakarta
}

\author{
Ni'matul Huda
}

\begin{abstract}
Pertaining to the 'lex posteriori derogat legi inferiori principle', the issuance of the Act No. 5, 1960 of UUPA (the Basic Principle of Agrarian Law) seems different. It results that the authority of the Yogyakarta Special Territory Province having its own rights to arrange land affairs as an autonomy authority based on the Act No. 3, 1950, becomes nullified. Despite the reality, the resolution of the fourth Dictum letter 'a' of the Basic Principle of Agrarian Law (UUPA) is bias. It states that since the Act is effective, rights and authority of the land and water of autonomous region or ex-autonomous region prevailing at the time become removed, and those change into State ownership since then. The arrangement of the fourth Dictum letter a will be settled in the forms of govemment regulation, and the govemment regulation itself has not been issued yet. In terms of its legal status, the ex-autonomous land in Yogyakarta Special Territory Province is unclear.
\end{abstract}

\section{Pendahuluan}

Pada 23 September 1960 Pemerintah mengeluarkan Undang-Undang Nomor 5 Tahun 1960 tentang Peraturan Dasar PokokPokok Agraria (UUPA). Dikeluarkannya UUPA ini dimaksudkan untuk menghilangkan dualisme dalam peraturan perundang-undangan keagrariaan (hukum agraria yang didasarkan pada hukum adat pada satu pihak dan hukum agraria yang didasarkan pada hukum Barat pada pihak lain). Namun, bagi Propinsi Daerah Istimewa Yogyakarta (DIY) dualisme tersebut tetap ada, bahkan waktu itu UUPA belum dapat diberlakukan.
Hal tersebut dapatlah dimaklumi oleh karena jauh sebelum dikeluarkannya UUPA di DIY telah terdapat peraturan perundangundangan daerah di bidang pertanahan yang dikeluarkan berdasarkan UU No. 3 Tahun 1950 jo UU No. 19 Tahun 1950 tentang Pembentukan Daerah istimewa Yogyakarta, berupa Rijksblad-rijksblad dan Peraturanperaturan Daerah.

Belum diberlakukannya UUPA di DIY mengakibatkan timbulnya dualisme dalam hukum pertanahan, di satu pihak berlaku peraturan perundang-undangan daerah, dan 
di pihak lain berlaku peraturan pemerintah pusat. Dualisme dalam hukum agraria.di:DIY jelas akan menimbulkan ketidakpastian hukum serta tidak. memberikan dukungan terwujudnya pembenahan kesatuan (unifikasi) hukum nasional.

UUPA baru dapat diberlakukan di DIY pada Tahun 1984, yaitu sejak dikeluarkannya Keputusan Presiden Nomor 33 tahun 1984 tentang Pemberlakuan Sepenuhnya UUPA di 'DIY. Keputusán' Presiden Nomor 33 Tahun 1984 menentukan bahwa pelaksanaan pemberlakuan UUPA secara penuh di Propinsi DIY diatur oleh Menteri Dalam Negeri. Untuk kepentingan tersebut dikeluarkanlah Keputusan Menteri Dalam Negeri No. 66 Tahun 1984 tentang Pelaksanaan Pemberlakuan Sepenuhnya UU No. 5. Tahun 1960 di Propinsi DIY.

Pemberlakuan sebuah UU dengan Keputusan Presiden bagi suatu daerah sesungguhnya tidaklah lazim, karena sejak UU itu dinyatakan berlaku di seluruh lindonesia, maka ia dengan sendirinya telah sah berlaku di masyarakat kecuali apabila di dalam UU tersebut memberikan pengecualian. Di samping itu, untuk berlakunya suatu peraturan perundang-undangan dikenal suatu lex posteriori derogat lex priori yaitu undang-undang yang berlaku belakangan membatalkan undang-undang yang berlaku terdahulu. Sehingga pemberlakuan UUPA di DIY tidak perlu diatur dengan Keputusan Presiden tetapi daerah secara bertahap harus melakukăn penyesuaian terhadap peraturan yang lebih tinggi.

Sejak UUPA berlaku secara penuh di DIY, dapat dikatakan telah tercapai suatu kodifikasi dan unifikasi hukum agraria di Indonesia. Akan tetapi, kenyataan menunjukkan masih terdapat 'kendala daläm melàksariakàn 'ketentuanketentuan UUPA khususnya yang berkaitan dengan tanah-tanah swaprajà atau bekas swapraja. Terhadap tanah-tanah' semacam ini, diktum Keempat UUPA menentukan 'sebagai berikut :

"A. Hak-hak dan wewenang atas bumi dan air dari swapraja atau bekas swapraja yang masih ada pada waktu mulai berlakunya Undang-undang ini hapus dan beralih kepada Negara.

B. Hal-hal yang bersangkutan dengan ketentuan dalam huruf $A$ di atas diatur lebih lanjut dengan Peraturan Pemerintah."

Oleh karena pengaturan lebih lanjut peralihan tanah bekas swapraja kepada Negara sebagaimana ditentukan dalam diktum Keempat huruf $A$ itu akan diatur dengan peraturan pemerintah, maka dengan sendirinya tanah-tanah bekas swapraja tersebut tidak dapat segera dialihkan karena sampai saat ini peraturan pemerintah sebagaimana dimaksùd diktum Keempat huruf $B$ belum ada. Hal ini antara lain yang menghambat proses peralihan itu, sehingga di DIY terkesan 'pengaturan pertanahannya masih mendua.

\section{Perkembangan Pengaturan Pertanahan di Propinsi DIY}

Sejak permulaan abad kesembilan belas, orang-orang asing sudah mulai mengadakan usaha di daerah Surakarta dan Yogyakarta yang dulu disebut Vorstenlanden. Di daerahdaerah tersebut. semua tanah dianggap kepunyaan Raja. Rakyat hanyalah sekedar memakainya saja (anggadhuh). Mereka ini 
diwajibkan menyerahkan sebagian (1/2 atau 1/3) dari hasil tanahnya itu kepada Raja, jika yang dikuasainya itu tanah pertanian atau melakukan kerja paksa jika tanahnya pekarangan. Kepada anggota-anggota keluarganya dan hamba-hambanya yang berjasa atau setia, oleh Raja (para patuh) diberikan tanah-tanah sebagai nafkah. Pemberian tanah itu disertai pula pelimpahan hak Raja atas bagian hasil tanah tersebut di atas. Mereka pun berhak menuntut kerja paksa. Stelsel ini disebut stelsel apanage.'

Untuk memungut sebagian hasil tanaman rakyat itu ditempatkanlah oleh Raja atau pemegang apanage orang-orang yang disebut "bekel. Para bekel ini mendapat $1 / 5$ dari tanah rakyat. Bagi rakyat jadi tinggal 4/5. Dari sisa ini $1 / 2$ diminta oleh pengusaha. Jadi tanah yang diusahakan sendiri oleh rakyat tinggal $2 / 5$ saja. Selain itu rakyat wajib melakukan pekerjaan bagi pengusaha, yang sama dengan yang dilakukannya untuk mengusahakan tanah yang $1 / 2$ atau $1 / 3$ itu jika ia menanaminya sendiri dengan tanaman rakyat. Dengan demikian maka terjaminlah bagi pengusah dua hal sekaligus, yaitu tanah dan tenaga buruh cumacuma. Kalau pekerjaan yang harus dilakukan itu melebihi pekerjaan biasa, maka rakyat barulah diberi upah.

Untuk mengurangi penyalahgunaan yang akan menambah beban rakyat diadakanlah reorganisasi hukum agraria, yang bertujuan untuk memberi kedudukan yang layak kepada rakyat tani. Salah satu usaha awal untuk merealisasikan rencana tersebut stelsel apanage dihapuskan, pada tahun 1914 (di Yogyakarta) dan 1918. (di Surakarta).

Sebelum reorganisasi 1914 , menurut Notoyudo, ${ }^{2}$ penggunaan tanah Kasultanan Yogyakarta dapat dikelompokkan sebagai berikut:

1. Tanah yang dipakai sendiri oleh Sri Sultan untuk Kraton dengan segala perlengkapannya, yaitu alun-alun, pagelaran, sitihinggil, mendungan (keben), sri manganti dan kraton. Tanah tersebut di atas disebut Tanah Keprabon.

2. Tanah yang oleh Sri Sultan diserahkan dengan cuma-cuma untuk dipakai, kepada Pemerintah Belanda (Gupernement) NIS, untuk benteng Vredeberg, kantor karisidenan, stasiun - kereta api.

3. Tanah-tanah yng diberikan kepada orangorang Belanda dan Tionghoa dengan hak eigendom/opstal.

4. Tanah golongan yaitu tanah-tanah yang diberikan oleh Sri Sultan kepada golongan-golongan.

5. Tanah kasentanan, yaitu tanah-tanah yang oleh Sri Sultan diberikan kepada kerabat/sentono dalem dengan hak pakai.

6. Tanah pekarangan Bupati, semula termasuk tanah golongan tetapi lambat laun dilepaskan dari ikatan golongan dan menjadi tanah pekarangan dari pegawaipegawai lebih tinggi lainnya dengan kampung-kampung di sekelilingnya.

'Boedi Harsono. 1975. Hukum Agraria Indonesia. Bagian Pertama. Jilid I. Cetakan Keempat. Jakarta: Djambatan. HIm. 71.

${ }^{2}$ Notoyudo. 1975. Hak Sri Sultan Atas Tanah di Yogyakarta. Yogyakarta: Tanpa Penerbit. 
7. Tanah kebonan; yaitu tanah yang ditanami pohon-pohonan, dan buahbuahan serta pekarangan, biasanya terletak di luar pusat ibukota yang diberikan kepada Pepatih Dalem dengan hak pakai.

8. Tanah rakyat biasa, yaitu tanah yang tidak termasuk jenis tanah tersebut di atas yang diletakkan langsung di bawah pemerintahan Kepatihan.

9. Sawah-sawah yang diurus oleh bekelbekel (tanah maosan dalem).

Masa-masa sebelum reorganisasi itu disebut masa "Kepatuhan" dan "Kebekelan", diatur berdasarkan Prantan Patuh 1863. Werner Roll menulis bahwa reorganisasi atau reformasi agraria yang dilaksanakan antara tahun 1912 dan 1918 menghasilkan aturanaturan baru, yakni: ${ }^{3}$

a. Penghapusan sistem feodal beserta tindakan-tindakan sewenang-wenang yang sudah membudaya.

b. Beberapa kesatuan tempat tinggal (desa; dukuh; kebekelan) digabung menjadi kesatuan administrasi baru seperti kelurahan atau desa praja.

c. Raja melepaskan hak-hak mereka atas sebagian terbesar dari tanah yang termasuk wilyah kesatuan administrasi ini, yang kemudian menjadi wewenang anggaduh (hak milik pribumi) anggota masyarakat desa.

d. Diadakan pembagian baru dari persilpersil tanah dan tanah garapan untuk penduduk desa dan disesuaikan pada kebutuhan tertentu dari usaha pertanian Belanda.

Dengan reorganissi ini, kabekelankabekelan digabungkan menjadi kelurahankelurahan yang mempunyai tugas administratif. Dibentuklah pemerintahan kelurahian dan dibuat pula register-register untuk mencatat keadaan tanah. Semua tanah diambil kembali oleh Raja dan para bekas pemegang apanage mendapat tunjangan berupa uang setiap bulan. Raja memberikan tanahnya dengan hak milik kepada kelurahankelurahan sebagai hak milik komunal. selanjutnya Werner Roll menulis: ${ }^{4}$

"Hak milik tanah tersebut beserta hak-hak istimewanya tetap di tangan raja-raja demi "kepentingan umum", yaitu de fakto hakhak ini dimảksud untuk kepentingan rajaraja atau bagi usaha pertanian Belanda. 'Hak milik komunal pribumi' yang diberikan kepada desa sebagai instansi yang mengawasi tanah milik secara formal, sebetulnya tidak lebih daripada hanya sebagai hak pakai secara komunal dan sangat terbatas."

Kepada rakyat diberi hak pakai turun temurun atas $4 / 5$ bagian dari sawah dan tegalan dari suatu kelurahan, sedang yang $1 /$ 5 bagian disediakan untuk tanah jabatan, tanah pengarem-arem dan tanah kas desa. Bekel yang dianggap cakap diberi tempat di pemerintahan kelurahan dan menerima tanah jabatan sebagai pamong kelurahan. Kalau ia

\footnotetext{
${ }^{3}$ Werner Roll. 1983. Struktur Pemilikan Tanah di Indonesia: StudiKasus Daerah Surakarta-Jateng. Jakarta: Rajawali. HIm. 45.

4/bid. HIm. 57.
} 
tidak duduk dalam pemerintahan kelurahan maka untuk selama hidupnya ia mendapat tanah pengarem-arem (tanah pensiun). Kalai ia meninggal, maka tanah pengarem-arem ini digabungkan dengan tanah kas desa.

Dengan Rijksblad Kasultanan (selanjutnya disingkat RK) tahun 1918 No. 16 dan Rijksblad Paku Alaman (disingkat RPA) tahun 1918 No. 18, kedua Kerajaan itu menyatakan kekuasaannya atas tanah dalam wilayah kerajaannya sebagai berikut:

"Sakabehe bumi kang ora ana tanda yektine kadarbe ing liyan mawa wewenang eigendom, dadi bumi kagungane kraton ingsun Ngayogyakarta (semua bumi yang tidak terbukti dimiliki oleh orang lain dengan hak eigendom, adalah kepunyaan kerajaan (ku) Ngayogyakarta)."

Atas dasar pernyataan domein itu Pemerintah Kasultanan dan Paku Alaman memberikan hak pakaihwewenang anggaduh kepada desa-desa (Pasal 3 ayat 1) yang harus dibentuknya. Kemudian berdasarkan RK No. 6 Tahun 1962 dan RPA No. 26 Tahun 1925 hak anggaduh dari desa itu diubah menjadi hak andarbeni atau wewenang andarbeni. Tanah-tanah yang berada di luar ketentuan Pasal 3 ayat 1 tersebut tidak termasuk wewenang Desa (RK No. 11 tahun 1911 dan RPA No. 15 tahun 1919), namun demikian bila Pemerintah Kasultanan atau Paku Alaman tidak memakainya, desa dapat menggunakan atau desa dapat mohon untuk dijadikan tanah desa atau tanah rakyat. ${ }^{5}$
Atas tanah-tanah yang berada di bawah kekuasaan Desa diberi wewenang antara lain:

1. menentukan peruntukannya (Pasal 4 jo Pasal 7 RK No. 16 tahun 1918 dan RPA No. 18 tahun 1918) sebagai:

a. tanah bengkok (gaji) bagi pejabatpejabat desa yang masih aktif;

b. tanah pengarem-arem (pensiun) bagi pejabat-pejabat desa yang telah berhenti dengan hak mendapat pensiun;

2. mengatur sendiri mengenai:

a) memindahkan sementara, misalnya menjual sewa (adol sewa).

b) memindahkan untuk dipakai turun temurun dengan memperhatikan ketentuan Pasal 4 RK №. 16 Tahun 1918 dan RPA No. 18 Tahun 1918.

3. Mengatur dan mengawasi agar tidak timbul penumpukan atau akumulasi tanah pada seseorang (RK No. 16 Tahun 1930 dan RPA No. 39 Tahun 1928). Mengenai berapa luas tanah yang dapat dikuasai seseorang hingga dapat dinilai sebagai tuan tanah diserahkan kepada masingmasing desa mengingat keadaan setempat saja. Dalam praktik tergantung kepada aktivitas desa diadakan atau tidak.

4. memutus masalah-masalah pemindahan hak atas tanah yang dilakukan dengan cara lintiran (warisan).

5Soedarso. 1987. "Pengaruh Undang-Undang Pokok Agraria Terhadap Tanah Adat di Daerah Istimewa Yogyakarta". Dalam BPHN, Simposium Undang_undang PokokAgraria dan Kedudukan Tanah-Tanah Adat Dewasa Ini. Cetakan Pertama. Jakarta: Binacipta. Him. 297. 
Dalam melaksanakan kewenangankewenangan tersebut desa dibatasi oleh peraturan, bahwa desa tidak boleh memperalihkan untuk selama-lamanya dan membebani tanah desa dengan hutang, kecuali dengan kuasa tertulis dari Bupati atau Assisten Residen yang bersangkutan (Pasal 13 sub b RK No. 22 Tahun 1918 dan RPA No. 24 Tahun 1918). Perijinan dari Assisten Residen ini secara diam-diam dihapus oleh Pasal 2 ayat (1) dari RK No. 23 Tahun 1925.

Selain daripada itu wewenang andharbeni itu dapat dicabut (kapundut kundur) apabila:

1. dalam waktu 10 tahun berturut-turut tidak dikerjakan atau tidak didiami (Pasal 3 ayat (2) RK No. 16 Tahun 1918 dan RPA No. 18 Tahun 1918);

2. diperlukan untuk kepentingan umum dengan penggantian kerugian (Pasal 5 jo. Pasal 6$)$.

Dengan adanya reorganisasi, maka terhadap tanah-tanah yang berhubungan dengan kepentingan raja beserta keluarganya sebenarnya tidak mengalami perubahan. Sedangkan yang mengalami perubahan adalah hak yang berhubungan dengan kepentingan rakyat. Hak-hak tersebut dapat dikemukakan sebagai berikut:

\section{Hak Pakai Turun Temurun}

Pemberian hak pakai turun temurun/hak anganggo turun temurun, lahir sebagai akibat dikeluarkannya RK No. 16 Tahun 1918 dan RPA No. 18 Tahun 1918, sebagai upaya untuk memberikan hak yang lebih kuat kepada rakyat. Mengenai apakah arti penting wewenang anganggo turun temurun ini tidak diketemukan penjelasannya, namun demikian dalam kenyataan rakyat dapat mewarisi haknya itu kepada keturunannya bahkan dapat memperalihkan haknya itu untuk sementara atau untuk selama-lamanya, seperti halnya terhadap tanah milik saja. Hak semacam ini hanya diberikan kepada rakyat di Kabupaten Gunung Kidul dan Kulon Progo. Di kedua daerah ini sebelum reorganisasi disebut tanah maosan dalem, sedangkan di daerah-daerah yang terletak antara sungai Progo dan Opak bukan tanah maosan dalem, sebab digunakan lungguh para Patuh. Namun dengan dihapuskannya Patuh, tanah tersebut kemudian diberikan kepada rakyat dengan hak anganggo turun temurun dengan kewajiban membayar pajak.

\section{Hak Andarbeni (memiliki)}

Hak ini diberikan kepada para pemakai tanah di dalam Kotapraja Yogyakarta berdasarkan RK No. 23 Tahun 1925 Bab ! angka 2. Terhadap tanah-tanah yang telah diberikan kepada rakyat baik hak anganggo turun temurun maupun hak andarbeni dikenakan kewajiban untuk membayar pajak (RK No. 24 Tahun 1925 Bab I angka 1). Di samping kewajiban membayar pajak ada juga larangan mengalihkan, menyewakan ataupun menggadhuhkan hak milik atas tanahnya kepada orang bukan bangsa Jawa (Indonesia), sebagaimana tercantum dalam RK No. 23 Tahun 1925 Bab VI. Peralihan hak andarbeni baik untuk selama-lamanya maupun untuk sementara (liyeran, sende) hanya dapat terjadi dengan cara balik nama dan pencatatan perubahan dalam daftar pendaftaran tanah di Kantor Urusan Tanah. Demikian pula peralihan yang didasarkan lintiran/warisan. 


\section{Hak Pungut Hasil}

Hak ini merupakan hak yang dapat dimiliki oleh seseorang dengan cara menanami atau mengusahakan terhadap tanah bukan miliknya dengan seijin Kepala Persekutuan (Kepala Desa).

\section{Hak didahulukan}

Hak yang dimiliki oleh seseorang dari warga persekutuan terhadap orang dari warga persekutuan lain, dengan demikian orang tersebut memperoleh hak-hak didahulukan dari warga tuar yang sama-sama menghendaki untuk mengerjakan tanah yang bersangkutan.

\section{Hak blengket}

Hak ini merupakan hak untuk didahulukan membeli tanah yang letaknya bersebelahan, jika tanah tersebut akan dijual. Jika hak ini tidak digunakan maka hak tersebut diberikan kepada orang lain yang sewarga, dengan syarat harga umum atau yang telah disepakati.

Hak-hak yang berhubungan dengan tanah seperti dikemukakan di atas merupakan hak yang dikenal dalam hukum adat. Selain itu akibat penjajahan Belanda, pada daerahdaerah yang dikuasai Belanda, berlaku juga hukum tanah Barat, khususnya di Yogyakarta. Dasar-dasar aturan hukum tanah yang dipergunakan antara lain adalah sebagai berikut: 6

1. Asas Domeinverklaring - Agrarisch Besluit (S. 1870 No. 118).
2. Staatsblad 1875 No. 179 - larangan penjualan tanah dari bangsa Indonesia kepada bukan bangsa Indonesia (Vervreemdingsverbod).

3. Staatsblad 1915 No. 474 tentang penetapan hak kebendaan oleh swapraja. Staatsblad 1884 No. 9 dan Staatsblad 1906 No. 93 peraturan mengenai landhuur.

4. Burgerlijk Wetboek (BW) atau Kitab Undang-undang Hukum Perdata (KUH Perdata)

Tanah yang diatur menurut hukum perdata Barat (BW) antara lain terdiri dari:

1. Tanah Recht van Eigendom

Tanah yang berstatus recht van eigendom ini berpangkal pada Pasal 570 BW, yaitu hak untuk mempunyai kenikmatan yang bebas atas suatu benda dan untuk menguasai itu dengan cara seluas-luasnya, asal tidak dipergunakan bertentangan dengan undang-undang atau peraturan umum yang diadakan oleh kekuasaan yang berwenang untuk mengadakan itu dan asal tidak menimbulkan gangguan terhadap hak-hak orang lain.

Di daerah Gubernemen (di luar Yogyakarta dan Surakarta), pemerintah kolonial Belanda memberikannya atas dasar Pasal 51 ayat (2) IS, dengan pembatasan:

a. Hanya digunakan untuk perluasan kota, desa dan untuk keperluan kuburan.

${ }^{8}$ Hadisuprapto. 1976. Ikhtisar Perkembangan Hukum Tanah Daerah Istimewa Yogyakarta. Yogyakarta: Karya Kencana. Hlm. 8. 
b. Untuk mendirikan dan memperluas bangunan kerajinan.

c. Luasnya tidak lebih 10 bahu.

Hak ini dapat diberikan kepada semua orang termasuk bangsa Indonesia. Sedanigkan di daerah Yogyakarta pemberian dilakukan oleh Raja dan hanya diberikan kepada bukan bangsa Indonesia dan digunakan untuk mendirikan pabrik, rumah-rumah dan sebagainya.

2. Tanah Recht van Opstal

Tanah yang dibebani dengan hak recht van opstal diatur dalam Pasal 711 BW, yang menyatakan bahwa hak opstal ialah hak kebendaan untuk mempunyai gedung-gedung, bangunan-bangunan dan penanaman di atas pekarangan orang lain.

Hak opstal ini biasanya hanya berlaku 30 tahun dan apabila ada persetujuan kedua belah pihak dapat diperpanjang lagi. Tanah yang dibebani dengan hak opstal ini biasanya diperuntukkan bangunan-bangunan untuk dihuni oleh para pengusaha perkebunan/pertanian di sekitar pabrik-pabrik atau di kota-kota maupun di tempat-tempat peristirahatan mereka. Bilamana waktunya sudah habis akan tetapi tidak minta perpanjangan waktu lagi, maka bangunan beserta tanamannya yang berada di atasnya menjadi milik dari pemilik tanahnya dengan memberi ganti kerugian harga bangunan beserta tanamannya itu. Selama pemilik tanah belum memberi ganti kerugian bangunan-bangunan beserta tanamannya itu pemilik hak opstal masih diperbolehkan menempatinya.

\section{3.: Tanah Recht van Erpacht}

Tanah dengan hak erpacht ini terdapat pengaturannya dalam Pasal 720 BW yang mengatakan bahwa erpacht ialah hak kebendaan untuk mendapatkan kenikmatan sepenuhnya dari benda tetap orang lain dengan syarat membayar erpacht setiap tahun sebagai pengakuan terhadap milik orang lain. Biasanya dipergunakan untuk perkebunan dan perusahaan pertanian dalam jangka waktu 75 tahun.

4. Tanah Recht van Vruchtgebruik

Tanah yang dibebani dengan hak recht van vruchtgebruik (hak pungut hasil) diatur dalam Pasal 756 BW yang mengatakan bahwa hak pakai hasil adalah suatu hak kebendaan, dengan mana orang diperbolehkan menarik segaala hasil dari sesuatu kebendaan milik orang lain, seolah-olah dia sendiri pemilik kebendaan itu, dengan kewajiban memelihara sebaik mungkin. Hak pungut hasil ini gugur (hilang) atau berakhir bila si pemakai telah meninggal dunia atau karena lewatnya waktu yang telah ditentukan. Ataupun karena pencampurn hak misalnya karena pemegang hak pakai hasil membeli bidang tanah-tanahnya tersebut. Dapat pula terjadi bilamana tanahnya musnah.

5. Tanah yang dibebani (hypotheek)

Hipotik ini merupakan hak kebendaan juga atas benda-benda tak bergerak, untuk mengambil penggantian daripadanya bagi pengluasan suatu perikatan (Pasal 1162 BW). Jadi tanah 
yang dibebani hipotik berarti tanah itu dibebani pula suatu ikatan perjanjian pinjam meminjam uang.

Meskipun secara de jure tanah dikuasai oleh Sultan, tetapi secara de facto tanah-tanah tersebut telah didistribusikan kepada orang perorangan atau golongan untuk digunakan menurut kebutuhannya masing-masing. Pengaturan selengkapnya tanah-tanah tersebut sebagai berikut:

1. Tanah yang dipakai sendiri oleh Sultan, ada dua macam yaitu tanah untuk keraton dengan segala perlengkapannya (tanah keprabon), dan tanah untuk makam raja-raja dan Putra Sentana Dalem.

2. Tanah yang diberikan dengan hak pakai kepada Pemerintah Hindia Belanda, kantor-kantor, asrama militer, Kereta Api dan sebagainya.

3. Tanah yang diberikan kepada NIS untuk keperluan jalan Kereta Api, dengan hak konsesi (tanah ini telah habis kontraknya tahun 1971, tetapi belum dikembalikan kepada pihak keraton).

4. Tanah yang diberikan kepada orang asing dengan hak eigendom dan opstal.

5. Tanah yang diberikan kepada onderneming untuk emplasemen pabrik dan perusahaan pegawainya dengan hak konsesi. Tanah ini juga telah habis masa kontraknya.

6. Tanah yang diberikan dengan hak pakai kepada kerabat/sentana (tanah kasentanan).

7. Tanah yang diberikan karena jabatan para abdi dalem seperti Patih, Wedana

8. Tanah untuk pohon buah-buahan (tanah kebonan).
9. Tanah untuk pembina agama Islam (tanah mutihan).

10. Tanah untuk pejabat yang berjasa (tanah perdikan).

11. Tanah untuk rakyat di dalam kota diberikan dengan hak anganggo. Sejak 1925 berdasarkan Rijksblad 1925 No. 23 dan 24 diberikan hak milik dan didaftar pada Kantor Urusan Tanah Kodya Yogyakarta.

12. Tanah untuk rakyat di luar kota diberikan dengan hak anggarap. Dengan Rijksblad 1918 No. 16 diberikan hak anganggo turun temurun. Dengan Perda DIY 1954 No. 5, hak anganggo turun temurun itu diubah menjadi hak milik.

Tanah-tanah yang masih merupakan tanah keraton diurus oleh Kawedanan Hageng Punokawan Wahono Sarta Kriyo cq. Kantor Paniti Kismo Keraton Ngayogyakarta. Pembenahan dimulai dengan inventarisasi, registrasi, pengawasan, penelitian dan penerbitan penggunaan tanah-tanah tersebut. Setiap orang atau badan hukum yang mengunakan tanah keraton diwajibkan membuat perjanjian, yaitu:

1. Tanah Keraton oleh pemakainya tidak dapat dipindahtangankan, hanya hak-hak sementara di atasnya (magersari, ngindung, hak pakai, hak guna bangunan dapat dialihkan).

2. Tiap-tiap pemindahan hak sementara di atas tanah Keraton harus dengan ijin Keraton.

3. Semua warga negara RI dapat mengadakan peralihan-peralihan hak sementara tersebut di atas.

4. Karena UUPA khususnya PP No. 10 Tahun 1961 di DIY hanya berlaku terhadap tanah- 
tanah bekas hak Barat (eigendom dan opstal), maka tanah-tanah di luar hak tersebut belum mendapat Tanda'Bukti Hak/Sertifikat seperti dimaksud dalam PP No. 10 Tahun 1961.

5. Kecuali tanah Kaprabon (untuk-Keraton dan perlengkapannya), tanah-tanah di luamya dapat dimagersarikan/diindungkan.

6. Dalam lingkungan tembok benteng semua orang dapat ngindung/magersari kecuali orang asing dan keturunan asing.

7. Ngindung/magersari tidak dengan jangka waktu tertentu dan akan berakhir jika hak ngindung/magersari dikembalikan, dicabut, dialihkan, pengindung/magersari meninggal.

8. Jika pengindung/magersari tidak mentaati syarat-syarat perjanjian, haknya dapat dicabut.

9. Magersari tidak dikenakan uang sewa tanah, tetapi ngindung dikenakan uang sewa tanah (penanggalan).

Selain tanah-tanah di atas, masih ada lagi tanah-tanah yang diberikan kepada kesatuan prajurit, atau kepada abdi dalem yang berkeahlian khusus. Mereka ditempatkan secara berkelompok menurut kesatuannya dan masih dilestarikan namanya sampai saat ini menjadi nama daerah. Adapun prajurit yang mendapat tanah untuk tempat.tinggal itu adalah (1) Prajurit Wirabraja mendapat tanah di Wirabrajan; (2) Prajurit Ketanggung di Ketanggungan; (3) Prajurit Patangpuluh di
Patangpuluhan; (4) Prajurit Bugis' di Bugisan; (5) Prajurit Mantrijeron di Mantrijeron; (6) Prajurit Daeng di Daengan; (7) Prajurit Jogokaryo di Jogokaryan; (8) Prajurit Nyutro di Nyutran.

Sedangkan menurut profesinya, yaitu : (1) Para undagi (tukang kayu) mendapat tanah di Dagen; (2) Para Jlogro (tukang membuat nisan) di Jlagran; (3) Para juru gending di Gendingan; (4) Para pesiden di Pasindenan; (5) Para juru lampu di Siliran; (6) Para juru bludir (bordur) di Bludiran; (7) Para juru musik di Musikan.

Dikarenakan kurang tertibnya administrasi dan inventarisasi pertaanahan, saat ini sulit untuk mengetahui keberadaan sebagian besar tanah-tanah tersebut. Untuk tanah kebonan, tinggal terdapat di daerah Wonosari yang dipergunakan untuk persediaan kayu. Di daerah Kebumen dan purworejo -meskipun tidak terurus- juga masih terdapat tanah-tanah Mutihan. ${ }^{7}$

Reorganisasi dilaksanakan tidak secara bersama-sama tetapi per distrik. Untuk daerah Yogyakarta, pada tahun 1919 meliputi kota Yogyakarta, distrik Sagan, Playen, dan Ngawen; tahun. 1920 meliputi distrik Kotagede dan Ngemplak; tahun 1921 meliputi distrik Klegong dan Mlati; tahun 1922 meliputi distrik Sentolo, Pengasih, Galur, Jumeneng dan Imogiri; tahun 1923 meliputi distrik Cepit, Srandakan dan Kreteg; tahun 1924 meliputi distrik Wonosari dan Semanu. ${ }^{8}$

\footnotetext{
'Selayang'Pạndang Riwayat Pertanahan Keraton Ngayogyakarta, diterbitkan oleh Kantor:Paniti Kismo Keraton Ngayogyakarta.

${ }^{8}$ Tunjung, "Reorganisasi Sistem Pemilikan Tanah di Vorstenlanden Pada Awal Abad XX, Tesis Sarjana Sejarah, Universitas Gajah Mada, Yogyakarta, 1982, HIm. 81: Menurut Soedarisman P., reorganisasi pertanahan di Yogyakarta diadakan setelah terjadi kebakaran besar di Pajeksan Kidul. Tidak dijelaṣkan lebih
} 
Perlu dikemukakan di sini bahwa akhir periode kedua (reorganisasi agraria) ini tidak bisa dipastikan waktunya, karena sekitar tahun 1950-an terjadi banyak peristiwa penting yang berkaitan dengan bidang agraria, seperti dihapuskannya pajak kepala tahun 1946, digantikan pajak tanah dengan pajak pendapatan tahun 1951, dan diberikannya hak milik perseorangan turun temurun tahun 1954. Secara umum, Selo Soemarjan menyimpulkan bahwa di masa sebelum perubahan hukum tanah di tahun 1918 kaum tani hanya mempunyai kewajiban tidak mempunyai hak, bahwa antara 1918 dengan 1951 mereka mempunyai kewajiban dan hak, dan sejak dihapuskannya pajak tanah di tahun 1951 mereka hanya mempunyai hak dan boleh dikata tidak mempunyai kewajiban. ${ }^{9}$

Pada waktu berlakunya UU No.22 Tahun 1948 tentang Pemerintahan Daerah, Pemerintah mengeluarkan UU No. 3 Tahun 1950 tentang Pembentukan Daerah istimewa Yogyakarta. UU No. 3 Tahun 1950 yang kemudian diubah dan ditambah dengan UU No. 19 Tahun 1950 kecuali mengukuhkan nama dan wilayah DIY, juga menetapkan organ-organ daerah dan urusan-urusan yang diserahkan kepada Pemerintah DIY. Urusanurusan yang diserahkan antara lain urusan agraria, meliputi:
1. Penerimaan penyerahan hak eigendom atas tanah kepada Negeri (medebewind).

2. Penyerahan tanah Negara (beheersoverdracht) kepada jawatanjawatan atau kementrian lain, atau kepala daerah otonom (medebewind).

3. Pemberian ijin membalik nama hak eigendom dan opstal atas tanah jika salah satu pihak atau keduanya masuk golongan bangsa asing (medebewind).

4. Pengawasan pekerjaan daerah otonom di bawahnya tentang agraria (sebagian ada yang medebewind).

Atas dasar kewenangan yang ditentukan di dalam UU No. 3 Tahun 1950 tersebut, Pemerintah DIY kemudian mengadakan peraturan pertanahan dalam bentuk peraturanperaturan daerah. Peraturan Daerah No. 5 Tahun 1954 Pasal 2 memberi ketentuan bahwa hak atas tanah yang terletak di dalam Kota Besar (Kota Praja) Yogyakarta untuk sementara masih berlaku peraturan seperti termuat dalam RK Tahun 1925 No. 23 dan RPA Tahun 1925 No. 25. Sampai dengan tahun 1984 saat pemberlakuan UUPA secara penuh di DIY, Pemerintah DIY belum menghasilkan Peraturan Daerah yang baru, sehingga hak atas tanah di Kotamadya Yogyakarta masih diatur dengan aturan lama.

rinci kapan dan alasan-alasan atau latar belakang apakah hingga peristiwa kebakaran itu dijadikan momentum pelaksanaan reorganisasi. Lihat Soedarisman P, 1984. Tanggapan Atas Disertasi Berjudul Perubahan Sosial di Yogyakarta. Yogyakarta: Gajah Mada University Press. HIm. 19.

${ }^{9}$ Selo Soemarjan. 1991. Perubahan Sosial di Yogyakarta. Cetakan Ketiga. Yogyakarta: Gajah Mada University.Press. HIm. 177. 
Kendala dalam Penyelesaian Status Hukum Tanah bekas Swapraja

Indikasi yang menghambat Pemerintah Daerah Tingkat I DIY dalam menyelesaikan status hukum tanah Keraton Yogyakarta apabila diidentifikasi berkisar pada faktorfaktor: a) Hukum atau peraturan; b) Status tanah; c) Administrasi pertanahan; d) Kelembagaan; e) Budaya.

Ad. 1. Hukum atau peraturan. Jauh sebelum terbentuknya Daerah Istimewa Yogyakarta telah diatur berbagai peraturan perundang-undangan dalam 'bidang keagrariaan sebagaimana tertuang dalam $R K$ maupun RPA yang berdasar Pasal 4 Ayat (4) UU No. 3 Tahun 1950 tentang Pembentukan Daerah Istimewa Yogykarta masih tetap berlaku. Atas dasar kewenangan otonom yang diberikan oleh UU No. 3 Tahun 1950 tersebut, Pemerintah DIY mengeluarkan beberapa peraturan daerah yang mengatur urusan keagrariaan, yaitu Perda No. 5 Tahun 1954 tentang Hak Atas Tanah di DIY; Perda No. 10 Thun 1954 tentang Pelaksanaan Putusan Desa Mengenai Peralihan Hak Andarbe dari Kelurahan dan Hak Anganggo Turun Temurun atas tanah dan Perubahan Jenis Tanah di DIY; Perda No. 11 Tahun 1954 tentang Peralihan Hak Milik Perseorangan Turun Temurun atas Tanah; dan Perda No. 12 Tahun 1954 tentang Tanda Yang Sah bagi Hak Milik Perseorangan Turun Temurun atas Tanah.

Melalui Perda No. 5 Tahun 1954 ditetapkan bahwa hak atas tanah yang terletak di dalam Kota Besar/Kota Praja Yogyakarta untuk sementara masih berlaku peraturan seperti termuat dalam Rijksblad Kasultanan Tahun 1952 Nomor 23 dan Rijksblad Paku Alaman Tahun 1925 Nomor 25 (Pasal 1 dan 2).
Dari ketentuan Pasal 1 dan 2 tersebut dapat diketahui bahwa Perda No. 5 Tahun 1954 hanya mengatur hak atas tanah di kelurahan-kelurahan di luar kota praja Yogyakarta. Sedangkan untuk Kota Besar, sambil menunggu Perda yang baru, sementara masih berlaku Rijksblad-rijksblad tersebut di atas. Tetapi temyata sampai dengan tahun 1984 saat pemberlakuan UUPA secara penuh di DIY, Pemerintah DIY belum menghasilkan Perda yang baru, sehingga hak atas tanah di Kotamadya Yogyakarta masih diatur dengan aturan lama. Di samping itu, sampai saat ini Peraturan Pemerintah sebagaimana yang dimaksud diktum keempat huruf $B$ UUPA juga belum ada. Keadaan ini jelas menunjukkan tidak adanya keseragaman, kesatuan dan kepastian hukum.

Dalam rangka menselaraskan kewenangan urusan agraria di DIY dengan UU No. 5 Tahun 1960 (UUPA), Pemerintah DIY melalui Peraturan Daerah No. 3 Tahun 1984 tentang Pelaksanaan Berlaku Sepenuhnya UU No. 5 Tahun 1960 di Propinsi DIY, menggariskan pembenahan kewenangan agraria sebagai kewenangan dekosentrasi, dan menyatakan tidak berlaku lagi peraturan perundangundangan DIY yang mengatur tentang agraria.

Penegasan kewenangan otonom bidang agraria menjadi kewenangan dekosentrasi melalui Peraturan Daerah Propinsi DIY No. 3 Tahun 1984 tersebut justru menimbulkan kekacauan yuridis, karena penyerahan urusan agraria kepada DIY atas perintah undangundang yaitu UU No. 3 Tahun 1950 sebagai urusan pangkal. Dapatkah dalam tata hukum kita Peraturan Daerah mengganti ketentuan dalam Undang-undang? Pertanyaan yang demikian wajar karena di dalam tata urutan peraturan perundang-undangan sebagaimana 
diatur di dalam TAP MPRS No. XX/MPRS/1966 kedudukan Peraturan Daerah jauh di bawah. Undang-undang. Di samping itu .kaidah hukum yang berlaku menentukan peraturan yang lebih rendah tidak boleh bertentangan dengan peraturan yang lebih tinggi.

Sesuai dengan ketentuan dalam UU No. 5 Tahun 1974 tentang Pemerintahan di Daerah Pasal 9, ditegaskan bahwa sesuatu urusan pemerintah yang telah diserahkan kepada daerah dapat ditarik kembali dengan peraturan perundang-undangan yang setingkat. Artinya, apabila urusan agraria telah diserahkan sebagai urusan otonom kepada DIY, maka apabila urusan ini akan ditarik kembali harus dengan peraturan perundangundangan yang setingkat yaitu undangundang.

Di dalam UU No. 5 Tahun 1960 Pasal 2 Ayat (2) ditegaskan bahwa hak menguasai dari Negara pelaksanaannya dapat dikuasakan kepada daerah-daerah swatantra dan masyarakat-masyarakat hukum adat, sekedar diperlukan dan. tidak bertentangan dengan kepentingan nasional, menurut ketentuanketentuan Peraturan Pemerintah. Selanjutnya di dalam Penjelasan Pasal 2 Ayat (4) UUPA dinyatakan bahwa pelimpahañ wewenang untuk melaksanakan hak penguasaan kepada Negara atas' 'tanah itu merupakan medebëwind.

"Dári sikap ini jelaslah bahwa' wewenang agraria dàlam 'sistem:UUPA adalah pada Pemerintah Pusat, untuk itu Pemerintah Pusat perlu segera melakukan perubahan terhadap UU No. 3 Tahun 1950 jo UU No. 19 Tahun 1950 dengàn mencabut kewenangan agraria sebagi kewenangan medebewind (sesuai dengan Penjelasan Pasal 2 Ayat (4) UUPA).
Ad. 2 Status Tanah. Setelah UUPA diberlakukan secara penuh di DIY dengan Keputusan Presiden No. 33 Tahun 1984 jo Keputusan Menteri Dalam Negeri No. 66 Tahun 1984, ada satu hal yang perlu ditetapkan yaitu tentang penegasan konversi dan pendaftaran hak atas tanah hak milik perseorangan berdasarkan Perda No. 5 Tahun 1954. Di dalam Pasal 1 Keputusan Menteri Dalam Negeri tersebut ditegaskan bahwa hak milik perseorangan atas tanah berdasarkan Perda No. 5 Tahun 1954 adalah hak milik sebagaimana dimaksud dalam diktum kedua Pasal II Ketentuan-ketentuan konversi UUPA.

Pihak yang dapat mempunyai hak milik hanyalah orang seorang, baik sendiri maupun bersama-sama dengan orang lin. Karena itu perlu dipertanyakan bagaimanakah status Kraton Yogyakarta itu sendiri? Berdasarkan PP No. 38 Tahun 1963 tentang penetapan badanbadan hukum yang dapat mempunyai hak milik atas tanah adalah:

1. Bank-bank yang didirikan oleh negara

2. Perkumpulan-perkumpulan koperasi yang didirikan berdasarkan UU No. 79 Tahun 1958 (L.N. 1958 Nomor 139)

3. Badan-badan keagamaan, yang ditunjuk oleh Menteri Pertanian dan Agraria, setelah mendengar Menteri Agama

4. Badan-badan sosial yang 'ditunjuk oleh Menteri Dalam Negeri dan Dirjen Agraria.

Berdasarkan ketentuan tersebut di atas lembaga Kraton tidak termasuk badan-badan yang dapat mempunyai hak milik atas tanah.

; Namun demikian, Pasal 21 Ayat (2) UUPA beserta Penjelasan Umum II (5) menyatakan bahwa di mana perlu Pemerintah dengan dispensasi sewaktu-waktu dapat menunjuk sesuatu baḍan hukum untuk mendapat hak 
milik atas tanah guna perluasan yang langsung dengan usahanya. Dispensasi penunjukan sebagai badan hukum terhadap Keraton Yogyakarta sampai saat ini belum ada.

Mengenai tugas dan wewenang agraria dari swapraja atau bekas swapraja diatur dalam Keputusan Menteri Agraria No. SK 112/ $\mathrm{Ka} / 61$ yang kemudian diubah berturut-turut dengan Keputusan Menteri Pertanian dan Agraria No. SK XIII/5/Ka dan SK 4/Ka/1962. dalam melaksanakan Keputusan No. 112/Kal 61 maka dengan Surat Menteri Agraria tanggal 31 Mei 1961 No. SK 1/2/18 diberikan penegasan, bahwa jika pejabat yang benwenang yang ditunjuk oleh surat keputusan tersebut tidak ada di suatu daerah, maka tugas dan wewenang dengan sendirinya dijalankan oleh pejabat yang lebih tinggi, yang wilayah kerjanya meliputi daerah yang bersangkutan.

Di DIY (pada waktu itu) tidak ada pejabat agraria dari Departemen Agraria, urusan agraria ada pada Kepala DIY dan diselenggarakan oleh Kepala Dinas Agraria Yogyakarta. Sungguhpun di dalam SK 112/Ka/61 ditentukan lain, tetapi dalam praktek semua wewenang di pusatkan pada Kepala Daerah Istimewa. ${ }^{10}$

Pada tahun 1980 Pemerintah Keraton Yogyakarta melalui. KHP Wahana Sarta Kriyo (KHP Wahana Sarta KriyoNo. 10/WAKJ80) mengajukan permohonan untuk penegasan status tanah SG kepada Gubernur DIY. Atas dasar permohonan tersebut Gubernur DIY mengeluarkan Surat Gubernur Kepala Daerah DIY No. K1/IV/849/80 menegaskan status tanah Kraton Yogyakarta sebagai hak milik. Tindakan Pemerintah DIY mengeluarkan surat tersebut lebih merupakan tindakan kebijaksanaan, sebab pada prinsipnya Pemerintah tidak boleh bertindak atas alasan tidak ada aturan khususnya.

\section{Ad. 3 Administrasi Pertanahan.} Berdasarkan pengelolaan data dari desal kelurahan se Propinsi DIY tanah swapraja (SG dan PAG) yang ada di Propinsi DIY seluas $36.750 .631,13 \mathrm{~m} 2$, dengan perincian tiap Kabupaten/Kotamadya DATI II sebagai berikut:"1

1. Kotamadya DATI II Yogyakarta: $800.495,63 \mathrm{~m} 2$

2. Kotamadya DATI II Bantul: $16.697 .531 \mathrm{~m} 2$

3. Kotamadya DATI II Kulon Progo: $10.376 .018 \mathrm{~m} 2$

4. Kotamadya DATIII Gunung Kidul: $5.814 .976,50 \mathrm{~m} 2$

5. Kotamadya DATIII Sleman: $3.061 .610 \mathrm{~m} 2$

Dari luas tersebut di atas penggunaannya dapat digambarkan sebagai berikut:
1. Sawah
: $\quad 2.300 .133 \mathrm{~m} 2$
2. Tegalan $10.877 .067 \mathrm{~m} 2$
3. Pekarangan
$2.723 .134,04 \mathrm{~m} 2$
4. Lapangan Olahraga : $67.685 \mathrm{~m} 2$
5. Kuburan
$1.538 .015 \mathrm{~m} 2$
6. Lain-lain

${ }^{10}$ Boedi Harsono. 1975. Hukum Agraria Indonesia. Bagian Pertama. Jilid I. Cetakan Keempat. Jakarta: Djambatan. Hllm. 107.

"Laporan Hasil Pendataan Tanah Swapraja, disusun oleh Proyek Pensertifikatan Tanah Hak Milik, Biro Bina Pemerintahan Umum Setwilda Propinsi DIY Tahun 1992/1993. 
Di luar penggunaan tersebut di atas masih ada tetapi karena dalam pengisian data dari desa/kelurahan tidak lengkap, akibatnya jumlah dari perincian penggunaan tidak sama dengan jumlah keseluruhan. Jumlah keseluruhan seluas $36.750 .631,13 \mathrm{~m} 2$ dibandingkan dengan jumlah rincian $34.292 .169,53 \mathrm{~m} 2$ terdapat selisih $2.458 .461,60 \mathrm{~m} 2$. Selisih tersebut disebabkan karena:

1. Kondisi tanah tidak diketahui oleh Pemerintah Desa.

2. Telah habis terkikis sungai.

3. Dipakai untuk pembuatan jalan.

4. Dipakai untuk pembangunan pemerintah seperti irigasi, jembatan, tanggul dan sebaginya.

5. Berujud oro-oro/puncak gunung dan sebagainya.

Ad. 4. Kelembagaan. Lembaga Keraton Yogyakarta sampai saat ini belum mendapat penegasan status. Tanah-tanah Keraton Yogyakarta(SG) yang ada masih dikuasai oleh Keraton Yogyakarta, meskipun penggunaannya ada yang untuk kerabat Keraton, untuk fasilitas umum, Pemerintah Daerah, dan sebagainya sudah diserahkan kepada penduduk dengan suatu perjanjian (Magersari atau Ngindung).

Meskipun saat ini Keraton Yogyakarta menyatakan diri sebagai lembaga pelestari kebudayaan (Jawa) dan tidak lagi sebagai lembaga pemerintahan, tetapi dalam praktiknya segala urusan yang berkaitan dengan tanah Keraton pihak Paniti Kismo memegang peranan penting, khususnya dalam memberikan rekomendasi untuk permohonan berbagai perijinan (ijin mendirikan bangunan, jijn lokasi, ijin usaha) di lingkungan Pemerintah Daerah Kotamadya Yogyakarta maupun untuk lembaga-lembaga lain yang memerlukan (misalnya Telkom, PLN, PDAM, dan Bank).

Ad. 5. Budaya. Sebagai daerah bekas kerajaan, meskipun Pemerintah Keraton Yogyakarta sudah berintegrasi dengan Pemerintah RI tahun 1945, namun kenyataannya pengaruh Pemerintah Keraton masih sangat terasa di masyarakat, di lingkungan birokrasi pemerintahan daerah dan swasta.

Masyarakat sampai saat ini masih sangat menghormati keberadaan Keraton Yogyakarta, yang diwakili oleh figur Sri Sultan Hamengku Buwono X. Sebagian besar pejabat pemerintah di lingkungan DIY merasa "rikuh dan pekewuh" apabila ingin mempermaslahkan tanh Keraton. Langkah yang ditempuh adalah mendiamkan pengaturan peruntukan tanah Keraton oleh Pemerintah Keraton sendiri.

\section{Upaya Untuk Mengatasi Hambatan}

Melihat beragamnya peraturan yang mengatur pertanahan di Propinsi DIY, Pemerintah kemudian melakukan pembenahan, antara lain mengadakan peninjauan kembali serta mencabut peraturan perundang-undangan daerah dalam bidang pertanahan yang telah dikeluarkan, yaitu:

a. Rijksblad-rijksblad Kasultanan dan Paku Alaman yang mengatur tentang keagrariaan yang masih berlaku.

b. Peraturan Daerah Istimewa Yogyakarta No. 5, 10,11 dan 12.

Teknis pembenahan tersebut dilakukan dengan cara mengeluarkan Peraturan Daerah tentäng Pencabutan Peraturan-peraturan 
Daerah, Rijksblad-njksblad yang bersangkutan yang mengatur masalah pertanahan dan dalam peraturan peralihannya ditetapkan "sambil menunggu" dikeluarkannya peraturan perundang-undangan yang memberlakukan UUPA secara penuh di Propinsi DIY, sementara masih berlaku peraturan yang lama. Di samping itu, Pemerintah DIY mengusulkan kepada Menteri Dalam Negeri untuk memikirkan kompensasi berkenaan hilangnya sumber pendapatan yang hilang sebagai akibat beralihnya penanganan dalam bidang pertanahan yang untuk tiap tahun berkisar Rp. 1,3 milyar.

Setelah melalui beberapa langkah penyesuaian dengan UUPA, akhirnya pada tanggal 9 Mei 1984 dikeluarkanlah Keputusan Presiden (Keppres) Republik Indonesia Nomor 33 Tahun 1984 tentang Pemberlkuan Sepenuhnya Undang-undang Nomor 5 Tahun 1960 di Propinsi DIY, yang berlaku surut sejak tanggal 1 April 1984. Keppres tersebut menentukan bahwa pelaksanaan pemberlakuan UU No. 5 tahun 1960 secara penuh di Propinsi DIY diatur oleh Menteri Dalam Negeri. Untuk memenuhi ketentuan tersebut maka dikeluarkanlah Keputusan Menteri Dalam Negeri Nomor 66 Tahun 1984 tentang Pelaksanaan Pemberlakuan Sepenuhnya UU No. 5 Tahun 1960 di Propinsi DIY. Menurut Kepmendagri tersebut, pemberlakuan sepenuhnya UU No. 5 Tahun 1960 di Propinsi DIY secara bertahap dimulai tanggal 24 September 1984.

Setelah dilakukan inventarisasi dan pembenahan terhadap tanah swapraja, langkah berikutnya adalah melakukan pendataan tanah secara serentak dan menyeluruh pada 1992/1993 berupa pencarian, pemasangan tanda batas serta pengukuran.

\section{Simpulan}

Dari uraian di atas dapat disimpulkan bahwa jauh sebelum UU No. 5. Tahun 1960 (UUPA) lahir urusan agraria di DIY telah diatur di dalam RK dan RPA dan beberapa Peraturan Daerah Istimewa Yogyakarta.

Undang-undang No. 3 Tahun 1950 tentang pembentukan DIY merupakan peraturan dasar yang pertama memberikan kewenangan atribusi kepada pemerintah DIY untuk mengatur urusan agraria. Setelah UUPA lahir, UU tersebut belum dapat dilaksanakan karena diktum keempat huruf $A$ dan $B$ ada penetapan bahwa pengaturan lebih lanjut terhadap tanah swapraja dan bekas swapraja akan diatur dengan Peraturan Pemerintah (PP) dan sampai saat ini PP yang dimaksud belum lahir. Untuk itu, seharusnya Pemerintah segera menerbitkan PP tersebut agar dualisme pengaturan dalam bidang pertanahan di Propinsi DIY segera berakhir. Di samping itu, status hukum tanah keraton perlu segera dipertegas agar tidak menimbulkan kerancuan dan duplikasi di dalam administrasinya.

\section{Daftar Pustaka}

Ateng Syafrudin. 1993. Pengaturan Koordinasi

Pemerintahan di Daerah. Bandung: CitraAditya Bakti.

Boedi Harsono 1975. Hukum Agraria Indonesia. Bagian Pertama. Jilid I. Cetakan Keempat. Jakarta: Djambatan.

Selo Soemarjan 1991. Perubahan Sosial di Yogyakarta. Cetakan Ketiga. Yogyakarta: Gadjah Mada University Press.

Seodarisman P. 1991. Tanggapan Atas Disertasi Berjudul Perubahan Sosial di Yogyakarta. 
Suhartono. 1991. Apanage dan Bekel Perubahan Sosial di Surakarta 1830. 1920. Yogyakarta: Tiara Wacana.

Tunjung. 1982. "Reorganisasi Sistem Pemilikan Tanah di Vorstenlanden Pada Awal Abad XX." Tesis Sarjana Sejarah. Yogyakarta: Universitas Gadjah Mada.

Werner Roll. 1983. Struktur Pemilikan Tanah di Indonesia; Studi Kasus Daerah Surakarta-Jateng. Jakarta: Rajawali.

BPHN. 1987. Simposium Undang-undang Pokok Agraria dan Kedudukan Tanahtanah Adat Dewasa Ini. Cetakan Pertama. Jakarta: Binacipta.

Proyek Pensertifikatan Tanah Hak Milik, Laporan Hasil Pendataan Tanah Swapraja, disusun oleh, Biro Bina Pemerintahan Umum Setwilda Propinsi DIY Tahun 1992/1993.

Undang-undang Nomor 3 Tahun 1950 tentang Pembentukan Daerah Istimewa Yogyakarta.

Undang-undang Nomor 5 Tahun 1960 tentang Peraturan Dasar Pokok-pokok Agraria.
Peraturan Pemerintah Nomor 38 Tahun 1963 tentang Penetapan Badan-badan Hukum yang Dapat Mempunyai Hak Milik Atas Tanah.

Keputusan Presiden Nomor 33 Tahun 1984 tentang Pemberlakuan Sepenuhnya UU Nomor 5 Tahun 1960 di Propinsi DIY.

Keputusan Menteri Dalam Negeri Nomor 66 Tahun 1984 tentang Pelaksanaan Pemberlakuan Sepenuhnya UU Nomor 5 Tahun 1960.

Peraturan Daerah Istimewa Yogyakarta Nomor 5 Tahun 1954 tentang Hak Atas Tanah diDIY.

Peraturan Daerah Kotamadya Yogyakarta Nomor 9 Tahun 1977 tentang ljin Tempat Usaha.

Peraturan Daerah Kotamadya Yogyakarta Nomor 5 Tahun 1988 tentang ljin Membangun Bangun-Bangunan dan ljin Penggunaan Bangun-Bangunan.

Peraturan daerah Kotamadya Yogyakarta Nomor 5 Tahun 1991 tentang Rencana Detail Tata Ruang Kotamadya. 